\begin{tabular}{lc}
\hline & ANNALES \\
& UNIVERSITATIS MARIAE CURIE-SKŁODOWSKA \\
LUL.V & SECTIO N \\
\hline
\end{tabular}

ISSN: 2451-0491 • e-ISSN: 2543-9340 - CC-BY 4.0 • DOI: 10.17951/en.2020.5.487-501

\title{
ICT, Media and Education - Some Considerations from the Brazilian Scenario
}

\section{ICT, media i edukacja - kilka uwag ze scenariusza brazylijskiego}

\author{
Fabiana Diniz Kurtz \\ Regional University of Northwestern Rio Grande do Sul State (Unijuí) \\ Rua do Comércio, 3000 Bairro Universitário - CEP 98700-000, Ijuí, RS, Brazil \\ fabiana.k@unijui.edu.br \\ https://orcid.org/0000-0001-8946-7480 \\ Denilson Rodrigues da Silva \\ Regional Integrated University of Upper Uruguai and Missions (URI) \\ Rua Universidade das Missões, 464 - CEP 98802-470, Santo Ângelo, RS, Brazil \\ denilsonrs@gmail.com \\ https://orcid.org/0000-0001-9264-6842
}

\begin{abstract}
Abstrakt. Brazylijski kontekst edukacyjny wykazał względny nacisk na to, co przewidują oficjalne dokumenty dotyczące jedynie „wykorzystania” ICT w przeciwieństwie do bardziej krytycznej postawy, która sytuuje te technologie jako instrumenty kulturowe o wymiarze wzmocnienia. W celu stworzenia teoretycznych i epistemologicznych ram dotyczących relacji między technologiami a edukacją niniejszy raport przedstawia koncepcje nieśmiało prezentowane w Brazylii, sformułowane na podstawie kompilacji badań opublikowanych w ciągu ostatnich pięciu lat na całym świecie.
\end{abstract}

Słowa kluczowe: ICT; media; narzędzia poznawcze; abstrakcja; perspektywa społeczno-historyczna 


\begin{abstract}
The Brazilian educational context has shown a relative emphasis on what official documents foresee with regard to the mere "use" of ICT as opposed to a more critical stance that situates these technologies as cultural instruments with an empowerment dimension. With the purpose of constituting a theoretical and epistemological framework around the relationship between technologies and education, this report presents concepts hitherto shyly presented in Brazil, on the basis of the compilation of studies published in the last five years worldwide.
\end{abstract}

Keywords: ICT; media; cognitive tools; abstraction; social-historical perspective

\title{
INTRODUCTION
}

Pedagogical practices in higher education, including teachers' education process, demand proposals capable of developing differentiated autonomy, competences and skills with future teachers, based on solid theoretical and conceptual pillars. From this perspective, the Brazilian educational context has shown certain shyness with respect to practices theoretically based around Information and Communication Technologies (ICT) that in fact enable a capacity for deep reflection on the limits and potential of these instruments in interaction with the historical-cultural context.

Considering recent studies conducted by our Research Group "Mongaba: education, languages and technology" (Kurtz 2015; Kurtz et al. 2016; Kurtz and Vargas 2017; Kurtz et al. 2018; Kurtz and Silva 2019), there is an immediate connection between what official documents provide (the country's educational legislation) and the training practice in teacher education courses. This was also verified recently by Denilson Rodrigues da Silva (2020), within technical areas like Computer Science, involving pedagogical dimensions linked to academic training in university courses.

This relationship to official documents precisely implies certain lack of conceptual and epistemological understanding both about ICT educational role and the pedagogical process itself. In studies still in progress, and with results yet to be published, we were able to verify, within the Research Group investigations, indications that the technicist scenario depicted from some of these official documents of exclusively "learning about" ICT does not seem to have changed substantially from what Kurtz (2015) verified about five years ago. On the contrary, what we perceive is that the need to "learn with" ICT with a strong theoretical basis as to its character as a cultural instrument that alters the flow of human actions (and conceptions) remains quite evident in Brazil.

We assume that ICT are cognitive tools, in David Jonassen (2000) terms, however, within a more recent theoretical scope, as "cultural instruments" that need to be developed as intellectual partners of the subjects, stimulating or 
facilitating critical thinking and higher-level learning. Such theoretical association is based on the assumption presented in Fabiana D. Kurtz (2016), that ICT are conceived as cultural instruments, which, once introduced in the flow of social activities, the qualitative changes of human actions become the focus and not only if they are for better or worse, making activities faster or slower, easier or more difficult. This perspective transcends, therefore, the focus (only) on quantitative changes brought about by such instruments.

In moments of behavioral transition such as the one experienced, the introduction of new forms of mediation or an older version of mediation can simply be reworked, restructured. This implies that changes in human development are always related to the emergence of new forms of mediation. This appearance, however, does not erase the previous forms, but simply reformulates them, improves them. Being (digital) literate is, therefore, an appropriation of new ways of reading, writing and communicating, in a process that involves multimodal elements (verbal and non-verbal), making it essential to look at concepts of "mediation" and "interaction", seeking to complement them due to the multisemiotic resources present in these cultural instruments.

This is undoubtedly one of the major changes that answers the question "What does it change?" with the dissemination of ICT in the social and educational sphere, which requires changes in curricular proposals both in teacher training and in basic education itself. Having Lev Vygotsky written in 1930, he obviously could not have included hardware and software in his writings; however, it is possible to perceive his theory, in the current context, as perfectly adequate, applying to these (new) cultural instruments. Hence the need to understand how these new forms of mediation by the computer can alter the flow and structure of mental functions, as "neo-Vygotskyan" James V. Wertsch (2002) stated almost a decade ago.

These questions have direct consequences on the process of teaching and learning, in all areas of knowledge, just like Silva (2020) observed in terms of the understanding of computational thinking and its underlying concepts by university professors in Computer Science. Knowledge about how the individual develops, learns, and lives in a historical-social context permeated by ICT, and the extent to which computers and other technologies can be configured as cognitive tools is a task for all areas.

For this reason, we present, in this article, a theoretical, conceptual and epistemological articulation around what we believe is necessary for the education field as well as for different areas in which the pedagogical process remains unclear, especially regarding the effective integration between ICT and education, with computational thinking as one of the highlights within this process. 
The elements presented here are twofold and follow questions raised since the beginning of the study: 1) To what extent dimensions like "teacher education" and "Education" are linked to concepts "cognitive tools", "computational thinking", and "ICT" within Brazilian scientific publications; and 2) the same question, however, related to the international scenario. Ultimately, the thesis supported is that ICT, media, and computational thinking subjects must be part of different educational instances given the need for undergraduate students in different areas to explicitly articulate competences and abilities that will not only be needed in the job market, but that assist them in their human and citizen development.

Abstraction, problem solving, critical and creative thinking, and logical reasoning are dimensions typically related to the concepts explored in the research, especially computational thinking. They are fundamental to human action in different social contexts and must be enhanced throughout their training process at an academic and professional level.

\section{METHODOLOGICAL ASPECTS OF THE STUDY}

According to the scenario described in the previous section, we choose to report, in this article, a theoretical, conceptual and epistemological articulation around the relationship between ICT, media and education, with an emphasis on teacher training. The elements presented here are the result of the search carried out in Brazilian and international research articles, dissertations and theses, from January 2015 to December 2019, both in Capes ${ }^{1}$ Journal Portal and in the search tool available in the reference management software, Mendeley ${ }^{2}$.

The second stage of the analysis, which is still in progress, will be carried out through textual discursive analysis, a qualitative research with an interpretive basis with the aim of organizing a conceptual and theoretical map explained by the corpus, which is composed of 140 texts. This stage of the research will be complemented with future data involving the values and conceptions of teachers working in teacher training and basic education regarding the role of the media and ICT in the educational process, either as an enhancer for the pedagogical process or as an element of innovation.

This first stage of the research concerned the search for academic texts based on the meaning attributed to the descriptors: "teacher training/education and

1 Coordination for the Improvement of Higher Education Personnel, a Brazilian research promotion agency, which has offered, since the year 2000, access to a portal of national and international journals in all areas of knowledge. Available at www.capes.gov.br [access: 10.08.2020].

2 Available at www.mendeley.com/?interaction_required=true [access: 10.08.2020]. 
ICT"; "media and education"; "computational thinking and education"; and "innovation in education".

The criteria for refining the search, which returned thousands of texts over the period in which we established monthly searches (from 2015 to 2019) focused on texts that had these descriptors in the titles or equivalent to these. More than 10,000 texts were compiled and, based on these texts, and with the aid of the qualitative analysis software ATLAS.ti, we will establish the analysis for the second stage of the research.

The analysis on the conceptual articulation in the texts, from the presented descriptors, even if in a preliminary way, demonstrates an association still timidly disseminated in Brazil, but quite deepened in other countries for some time, as pointed out by Shuchi Grover and Roy Pea (2013), Paul Curzon (2014), Matt Bower et al. (2015), and Caitlin Duncan et al. (2017).

In the next section, we present the "interlacing" of concepts verified in the preliminary analysis, with the aid of the qualitative analysis software ATLAS.ti. We also present social implications of the gaps left for the limited presence of elements that deepen understandings of what can be perceived as potentialities and limitations of ICT in education, closely linked to social and cultural values based on media education. It obviously transcends the almost exclusively instrumental character with which the theme is treated in these contexts, in school curricula and in teacher training courses.

After that, we try to explain one of the issues present in the theoretical scope linked to the concept of "computational thinking", which has emerged from this preliminary analysis. We believe that this subject must be one of the great themes that educators need to address, in order to avoid perpetuating a pedagogical process that limits students' reflective power, and extremely restricts what could be understood as their repertoire of scientific/media literacy.

\section{ICT IN TEACHER TRAINING ${ }^{3}$ : POSSIBLE SOCIO-CULTURAL IMPLICATIONS}

In order to conceive ICT as cultural instruments, it is important to establish that the theoretical support of this study is based on Vygotsky's $(2007 ; 2008)$ ideas, which are, in fact, increasingly more alive and necessary to explain, from the

\footnotetext{
3 We do not consider differences between "teacher training" and "teacher education" processes, despite some studies point to an epistemological difference in terms of technically "training" and processually/pedagogically "educating" teachers. Our intention here is to reach both dimensions, then the indiscriminate use of these terms.
} 
historical-cultural perspective, how the social and cultural system and the human cognitive functioning are altered by the introduction of (new) cultural instruments. Basic ideas launched by "neo-Vygotskian" researchers, such as Wertsch (2007) are fundamental in the sense of relating historical-cultural studies to the understanding of the human mind. It is in this sense that we assume that both cognitive processes such as human actions are guided by cultural instruments used by the subjects. Hence the urgent need to cease the exclusively technical and instrumental treatment attributed to ICT in the educational field, mainly.

When considering ICT as cultural instruments, in these terms, it is important to turn attention to the qualitative changes of these actions and not just to their development or to their quantitative character. Research that explores this pedagogical, conceptual and epistemological character of the relationship between ICT and education is increasingly necessary and urgent in the sense of implementing proposals that integrate technologies/media and education not in a technical sense, but for critical and emancipatory purposes.

Planning, memory, voluntary attention, language, among other functions, are not innate and are different from the more "rudimentary" actions, of an involuntary character, such as automated reflexes as Vygotsky stated decades ago, and that remain revisited. This would be the difference between higher psychological functions (or cultural ones, considering that they develop throughout the process of internalizing cultural forms of behavior, and do not happen directly, but mediated by instruments) and elementary functions.

When conceiving the process of internalizing higher mental functions, Vygotsky asserted that this transition to mediated activity, by artificial means, changes all psychological operations, in the same way that the use of instruments expands the range of activities in which new psychological functions operate. In this sense, ICT are equivalent to what Vygotsky referred to external stimuli that allow human beings to alter their development flow, something that differs from Piaget's writings.

As Kurtz (2016) has already observed, based on this perspective, to be human is to use cultural instruments or mediational means, considering that these instruments are not inventions independent of the subjects who use them. The fact that cultural instruments (or tools) change the conceptions of sociocultural setting, just like ICT (between subjects and instruments), allows to affirm that "knowing how" seems to "know this", when, in fact, mediation seems to take new proportions when conceiving ICT as cognitive tools, which, in fact, alter cognitive and cultural aspects of life of individuals.

Higher mental functions are culturally mediated because mind development is an interrelation between biological factors and the appropriation of the existing 
cultural and material heritage in order to "coordinate" people with each other and with the physical world. That is why higher functions do not involve direct action in the world, but indirect, benefiting from human work or practice already produced for a given purpose.

Thus, it seems inevitable that the behavioral changes that occur in society are the result of people's participation and interaction with the socio-historical context in which they live. One cannot assume an environmentalist position, in which the individual is passively shaped by the definitions of the environment in which he/she lives, as this is not the case. Following Vygotsky's historical-cultural approach, or the so-called "mediated perspective on social interactions", the individual appropriates the historical and cultural experience, internalizing cultural forms, which does not imply a passive process. On the contrary, at the same time, that the subject internalizes culture, he/she transforms and changes it.

Using ICT, therefore, not only changes the way people learn, but also "increases" existing learning. This totally contradicts conceptions of simple "use" of these instruments, as if they were merely instrumental. It is not the mere presence of stimuli that determines human behavior, but rather the new or transformed psychological situation created by humans, that is, what determines the behavior that distinguishes elementary from superior forms is the creation and use of artificial stimuli as means which help to understand someone's reactions. Human forms are, then, those that involve mediation.

Therefore, since ICT are human creations, their role are crucial in enhancing students' critical thinking. They are not tools that are only at the service of the population or teachers, but "intellectual partners" that empower subjects, providing them with elements that, from a critical perspective, help them to position themselves and act in the world.

Given the current circumstances regarding the implementation of technologies in the educational sphere, much more than meeting social, economic and intellectual needs of society, it is crucial to start from the assumption that the teacher is an intellectual. Based on this, it is essential that teachers have deep theoretical, conceptual and epistemological understandings about the role, potential and limitations of ICT in education within their training process, as we argue in this text.

\section{COMPUTATIONAL THINKING AND EDUCATION}

As already verified by Kurtz (2015), it is necessary to be clear that articulating teaching and technology, for many educators, is something that provokes certain distancing, often linked to a technical and instrumental concern. For 
many teachers, the theme itself becomes somewhat detached from reflections articulated to theories and concepts that permeate and constitute the teaching profession itself. There is the concern to reflect on aspects considered proper to "being a teacher of...", but when it comes to the role attributed to ICT in education, the subject is restricted to the "domain of...", as if these instruments "orbited", or were external to the pedagogical process. Considering this scenario, which is still noticeable today in some contexts, we realize that the concept of "computational thinking" (CT) has been, in several countries, associated with teacher training precisely in order to completely distance the instrumental concern from teaching.

According to Jeannette Wing (2014), this concept is based on the foundations of Computer Science and involves capacities and skills quite highlighted in documents that govern education in different countries and in the international literature proper to the educational sphere, as being something to be constituted by professionals - whether from the educational field or not. Among these skills are the resolution of complex problems, the understanding of human behavior, logical reasoning, evaluation, and the ability to abstract - and most interestingly - "even without the use of machines"!

However, there is still no consensus in the academic community on the definition of the concept of "computational thinking" and discussions on this definition are still ongoing (Brennan and Resnick 2012; Diordieva et al. 2019; Grover and Pea 2013; Tedre and Denning 2016). Christian P. Brackmann (2017) points out that, even after a decade of efforts to try to define computational thinking, there are still questions about the true meaning of the term and how this type of thinking can be evaluated.

For this reason, Brackmann proposes a broader and more detailed definition for the term, as a human capacity to use the fundamentals of Computing in different areas of knowledge, "with the purpose of identifying and solving problems, individually or collaboratively, through clear steps, in such a way that a person or a machine can execute them effectively" (Brackmann 2017: 29).

Another research initiative aimed at defining the contours and particularities of computational thinking was presented by Valerie Shute et al. (2017). In their article, the authors make a broad analysis of the various definitions provided in the international literature and synthesize a new definition. According to them, CT is "the conceptual basis necessary to solve problems effectively and efficiently (that is, algorithmically, with or without computer assistance) with reusable solutions in different contexts" (Shute et al. 2017: 150).

This definition shows that CT is fundamentally a way of thinking and acting, which can be visualized through the use of specific skills. Shute et al. (2017) 
categorize computational thinking into six main approaches or cognitive processes: decomposition, abstraction, algorithm design, debugging, iteration and generalization. Decomposition, involving breaking up a complex problem into smaller parts and using systematic processes to solve each of these minor problems; iterative and systematic debugging, ensuring that each part of the minor problems is resolved efficiently; abstraction as the act of finding patterns within problems and solutions - being in a position to generalize solutions to similar sets of problems; and the design of algorithms allows the development of reusable tools/procedures to solve classes of problems.

As Silva (2020) observes, there is a wide range of definitions around CT, especially with regard to the skills associated with this form of thinking. A widespread definition in the literature places the concept sustained from "four pillars" - decomposition, pattern recognition, abstraction and algorithms. We can also consider these components as four dimensions that represent the concepts and/ or skills that support this particular form of thinking. According to the literature, the four pillars are complementary to each other and make the problem-solving process interdependent.

In these terms, decomposition is associated with the ability to decompose a complex problem or system into smaller and more easily manageable parts. Pattern recognition makes it possible to identify similar characteristics and properties between and within problems. Abstraction refers to the ability to focus efforts only on important information and characteristics, ignoring details not relevant to a given problem; and the algorithms, which involve the ability to work out a solution to a given problem through well-defined steps and rules.

Besides this conceptual dimension, Cynthia Selby (2013) proposed a definition of computational thinking with a broad scope, highlighting the key concepts represented in Figure 1 as proposed by Silva (2020). Briefly, these five key concepts can be understood as: algorithmic thinking, which considers the ability to define precisely and clearly the steps necessary to solve problems; evaluation,

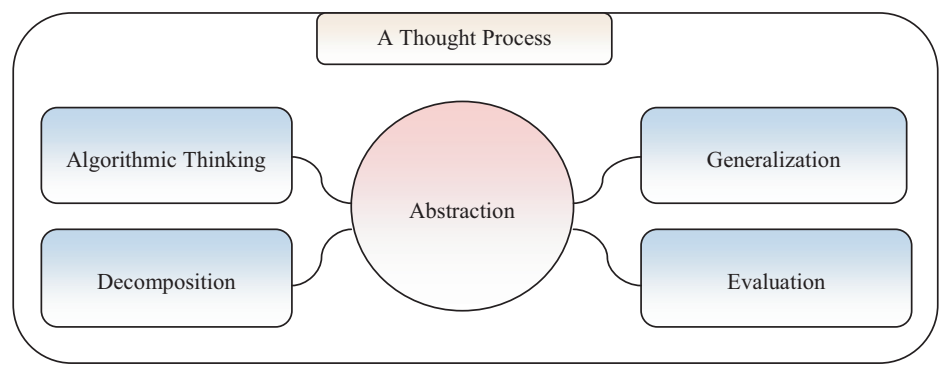

Figure 1. Key concepts of computational thinking (adapted from Silva 2020) 
which includes the ability to evaluate processes in terms of efficiency and use of resources, as well as the ability to recognize and evaluate results; decomposition, understood as a way of thinking about problems, algorithms, resources, artifacts, processes and systems in terms of their parts.

By analyzing the parts separately, it is easier to solve complex problems and design large-scale systems; generalization, as a cognitive process aimed at solving new problems based on similar solutions already established. This concept involves the ability to verify functional and structural characteristics common to different contexts and situations; and abstraction, which refers to the ability to select attributes and hide the complexity and details of implementation in a problem-solving process.

Considering this, the so-called " $21^{\text {st }}$-century skills" have contributed substantially to the realization of numerous reflections on education, at all levels, as well as on the pedagogical processes mediated by ICT. On the other hand, understanding about the role of these cultural instruments in the educational process is still a major challenge for teachers and students in Brazil.

Wing $(2010 ; 2014)$ supports the idea that all people (children, youth and adults), in their educational processes, should develop this way of thinking with the aim of constituting knowledge and skills previously attributed to Computer Science professionals. In this context, CT considers a set of mental processes (cognitive tools) used by computer professionals when they operate with a view to solving problems that can effectively involve all areas of human knowledge - in an inter/transdisciplinary perspective. Still, based on contributions from other researchers, Wing (2014) added the conception that the thought process involves formulating problems and expressing their solutions in such a way that human beings can effectively accomplish them in the most different areas and not just subjects directly involved with the computing area.

Since then, the scientific community and, especially, the international educational field, has been directing efforts to investigate the nature of this type of thinking and to verify ways for its insertion in school curricula and in teacher training processes, just like Cristina Diordieva et al. (2019) present, with a case study between Brazilian and American teachers.

We argue that computational thinking must be conceived as a competence, as it has a greater breadth and reach. It is the general objective to be achieved by computer professionals. In order to make this competency feasible, several skills of a particular order, of specific scope, i.e. the listed skills, must be developed to make this thinking effective as a higher competence. A visual representation of part of this conceptual system is shown in Figure 2. 


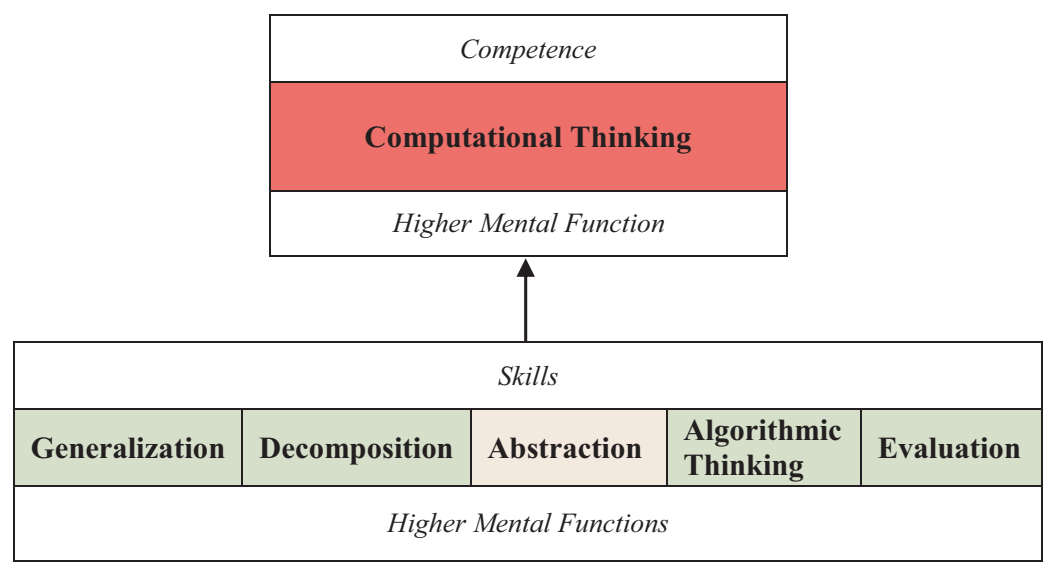

Figure 2. Computational thinking as a higher mental function (adapted from Silva 2020)

It is interesting to note that two important guiding documents such as Brazilian Curricular guidelines of the area and the training references for undergraduate courses (Zorzo et al. 2017) do not list computational thinking as a competence to be developed. They just indicate that the bachelor's degree courses in the field of computing must provide professional training that reveals the skills and competences to, among others, recognize the importance of computational thinking in everyday life and its application in appropriate circumstances and in different domains.

In these terms, it is important to highlight that the use of ICT in the teacher training process is not something new. In order to conceive a teaching and learning process, in the contemporary technological context, one cannot ignore the need to rethink the process of mediation, interaction, and the educator's own role in such a context.

Since the publication of Wing's original essay (2006), there has been considerable interest and research dedicated to incorporating computational thinking skills at all levels of school curricula. Government agencies and private interests, such as the National Science Foundation and British Royal Society, Microsoft and Google have supported these efforts. Therefore, we follow what Wing suggests, when considering computational thinking in an expansive way, as a cognitive structure and a "grouping" of problem-solving methods suitable for various disciplines. Arguably, computational thinking is a pre-existing component of many human efforts; the old formula of "computing = programming" is outdated. In this perspective, CT is "a new way of reasoning" that must be presented in as many contexts as possible. 


\section{CONCLUSIONS}

In view of the scenario that we seek to present and discuss in this text, we understand that the theoretical articulation carried out may help educators and professionals involved in teacher training with elements that, hopefully, should enable the proposition of parameters that surpass the technical and instrumental perspective regarding ICT in education, and reaches an effectively reflective and critical process with regard to the relationship of ICT in the world.

We believe it is urgent to introduce specific discussions not only about CT in teacher education programs, but, fundamentally, questions that articulate and expand these understandings to the scientific literacy process of these future teachers and, ultimately, of basic education students. This may enable a new look at education itself, which needs to innovate and review certain processes, and deserves investment.

Efforts to integrate ICT in teacher education are collective and must show that the principles of teaching linked to these technologies are the same, whether in person, distance or mixed (blended learning). Thus, the more teachers who engage in this integration process, the greater the possibility of spreading the potential of ICT in the process of teachers' training and throughout educational institutions in other areas.

Therefore, in times when Brazilian education has been so criticized, mainly for the low performance of students of basic education in national exams, it is fundamental to reflect on the current scenario, including school and teachers' role. The creation of new meanings to the generalized knowledge and experiences that are easily accessible to students, such as those provided by social networks and other instances of the "digital life" to which these subjects have access, are realized based on historical knowledge, constructed over time by individuals.

From the moment that this historical, classic and traditional knowledge starts to make sense to the student, the learning will, finally, be elevated to another level of abstraction that, in Vygotskian terms, means the possibility of awareness of the meaning that the cultural instruments and their own access to culture. This distinguishes what is secondary from what is primary: instrumental use is secondary. The essential thing is the awareness of the potential of cultural reconstruction in solving human problems. This is only possible if the meaning of what is easily found, daily and quickly, as the context permeated by ICT signals, is deepened and located in contexts other than those routinely conceived by students.

This aspect demands refinement, a gigantic theoretical specialization on the part of the teacher. It is certainly in the initial training course that it must be developed, considering the so-called use of ICT extended to a process that 
considers them as cultural instruments in a meaningful way, associated to the context with which the subjects interact. Otherwise, the posture remains that of considering ICT from an instrumental perspective, and social reality as something outside the school walls.

\section{REFERENCES}

\section{Literature}

Bower, M., Lister, R., Mason, R., Highfield, K., Wood, L. (2015). Teacher Conceptions of Computational Thinking - Implications for Policy and Practice. Australian Journal of Education, vol. 0(0).

Brackmann, C.P. (2017). Desenvolvimento do Pensamento Computacional Através de Atividades Desplugadas na Educação Básica. PhD Thesis.

Brennan, K., Resnick, M. (2012). New Frameworks for Studying and Assessing the Development of Computational Thinking. Paper presented at annual American Educational Research Association meeting, Vancouver, BC, Canada. Retrieved from: http://web.media.mit.edu/ kbrennan/files/Brennan_Resnick_AERA2012_CT.pdf [access: 12.01.2020].

Curzon, P., Dorling, M., Ng, T., Selby, C., Woollard, J. (2014). Developing Computational Thinking in the Classroom: A Framework. Computing at School. Retrieved from: https://eprints.soton.ac.uk/369594 [access: 19.02.2020].

Diordieva, C., Yeter, I., Smith, W.S. (2019). Middle School STEM Teachers' Understandings of Computational Thinking: A Case Study of Brazil and the USA. Paper presented at 2019 ASEE Annual Conference \& Exposition, Tampa, Florida, DOI: https://doi. org/10.18260/1-2--33107.

Duncan, C., Bell, T., Atlas, J. (2017). What do the Teachers Think? Introducing Computational Thinking in the Primary School Curriculum. Proceeding ACE '17 - Proceedings of the Nineteenth Australasian Computing Education Conference, Geelong, VIC, Australia, 65-74, DOI: https://doi.org/10.1145/3013499.3013506.

Grover, S., Pea, R. (2013). Computational Thinking in K-12: 2: A Review of the State of the Field. Educational Researcher, vol. 42(1), 38-43, DOI: https://doi. org/10.3102/0013189X12463051.

Jonassen, D.H. (2000). Computadores, ferramentas cognitivas: desenvolver o pensamento crítico nas escolas. Porto: Porto Editora.

Kurtz, F.D. (2015). As tecnologias de informação e comunicação na formação de professores de línguas à modalidade do trabalho: luz da abordagem histórico-cultural de Vigotski. PhD Thesis, Universidade Regional do Noroeste do Estado do Rio Grande do Sul. Educação nas Ciências, Brazil.

Kurtz, F.D. (2016). Ensino e aprendizagem "com" e não apenas "sobre" tecnologias: contribuições para o ensino superior e formação docente a partir da abordagem histórico-cultural de Vigotski. Ensino de Ciências e Tecnologia em Revista, vol. 6, 83-99, DOI: https://doi.org/10.20912/2237-4450/2016.v6i1.1672. 
Kurtz, F.D., Quevedo, M.F., Vargas, R.S. (2016). O papel das tecnologias de informação e comunicação na formação de professores: Uma pesquisa bibliográfica a partir da abordagem histórico-cultural de Vigotski. In: L.I. Allebrandt, M.B. Maldaner (Orgs.), Alfabetização numa relação intercultural (pp. 274-279). Ijuí: Unijuí.

Kurtz, F.D., Vargas, R.S. (2017). As tecnologias de informação e comunicação na formação docente em Letras: o TPACK como possibilidade de inovação teórica e metodológica. In: C.S. Toldo, M.S. Diedrich (Orgs.), Seminário de ensino de línguas estrangeiras (pp. 261-273). Passo Fundo: Universidade de Passo Fundo.

Kurtz, F.D., Vargas, R.S., Moura, R.O. (2018). Tecnologias e formação de professores de línguas: além de uma perspectiva técnica. Afluente, UFMA/Campus III, vol. 3(7), 139-158. Retrieved from: http://www.periodicoseletronicos.ufma.br/index.php/ afluente/article/view/9152 [access: 12.01.2020].

Kurtz, F.D., Silva, D.R. (2019). Pensamento computacional e formação de professores de língua portuguesa: articulações teóricas e epistemológicas envolvendo letramento digital em cursos de licenciatura. In: VII Simpósio Mundial de Estudos da Língua Portuguesa - SIMELP, Porto de Galinhas, Pernambuco, Brasil.

Selby, C. (2013). Computational thinking: the developing definition. Canterbury: University of Southampton (E-prints). Retrieved from: https://eprints.soton. ac.uk/356481 [access: 12.01 .2020 ].

Shute, V.J., Sun, C., Asbell-Clarke, J. (2017). Demystifying Computational Thinking. Educational Research Review, vol. 22, 142-158, DOI: https://doi.org/10.1016/j. edurev.2017.09.003.

Silva, D.R. (2020). Desenvolvimento do pensamento computacional como dimensão estruturante da atividade do professor de cursos superiores de computação. PhD Thesis, Universidade Regional do Noroeste do Estado do Rio Grande do Sul. Educação nas Ciências, Brazil.

Silva, D.R., Kurtz, F.D. (2017). Formação de professores e pensamento computacional: possibilidades conceituais e metodológicas. Anais do I EREC. Universidade Federal de Santa Maria, RS, Brazil.

Tedre, M., Denning, P.J. (2016). The long quest for computational thinking. Proceedings of the 16th Koli Calling International Conference on Computing Education Research - Koli Calling '16, 120-129, DOI: https://doi.org/10.1145/2999541.2999542.

Vigotski, L.S. (1896-1934) (2007). A formação social da mente: o desenvolvimento dos processos psicológicos superiores. $7^{\text {a }}$ edição. São Paulo: Martins Fontes.

Vigotski, L.S. (2008). Pensamento e linguagem. $4^{\text {a }}$ edição. São Paulo: Martins Fontes. Wertsch, J.V. (2002). Computer Mediation, PBL, and Dialogicality. Distance Education, vol. 23(1), 105-108, DOI: https://doi.org/10.1080/01587910220124008.

Wertsch, J.V. (2007). Mediation. In: H. Daniels, M. Cole, J.V. Wertsch (eds.), The Cambridge Companion to Vygotsky (pp. 178-192). Cambridge: Cambridge University Press.

Wing, J.M. (2006). Computational Thinking. Communications of the ACM, vol. 49(3), 33-35, DOI: https://doi.org/10.1145/1118178.1118215.

Wing, J.M. (2010). Computational Thinking: What and Why. Link Magazine, 20-23.

Wing, J.M. (2014). Computational Thinking Benefits Society. Social Issues in Computing. Retrieved from: http://socialissues.cs.toronto.edu/2014/01/computational-thinking [access: 12.01.2020]. 
Pobrane z czasopisma Annales N - Educatio Nova http://educatio.annales.umes.pl Data: 26/04/2023 13:38:13

Zorzo, A.F., Nunes, D., Matos, E.S., Steinmacher, I., Leite, J.C., ..., Martins, S. (2017). Referenciais de Formação para os Cursos de Graduação em Computação. Sociedade Brasileira de Computação (SBC).

\section{Websites}

www.capes.gov.br [access: 10.08.2020].

www.mendeley.com/?interaction_required=true [access: 10.08 .2020 ]. 